$\mathrm{A} \int_{\text {ass }} \mathrm{H}$

Article history :

Received : 12.11.2014

Revised : 28.03.2015

Accepted : 14.04.2015

Author for correspondence:

\section{R. KANDASAMY}

Department of Horticulture, Faculty

of Agriculture, Annamalai

University, ANNAMALAINAGAR

(T.N.) INDIA
THEASIAN JOURNAL OF HORTICULTURE

Volume 10 | Issue 1 | June, 2015 | 60-63

Visit us -www.researchjournal.co.in
RESEARCH PAPER

DOI : 10.15740/HAS/TAJH/10.1/60-63

\title{
Variability studies in okra (Abelmoschus esculentus L.)
}

\section{R. KANDASAMY}

ABSTRACT : Twenty five genotypes of okra collected from different districts of Tamil Nadu were evaluated to assess the variability, heritability, genetic advance. Morphological characters like days to first flowering, plant height, number of branches per plant, internodal length, node at first flowering, days to first fruit harvest, fruit length, fruit girth, fruit weight, number of fruits per plant, 1000 seed weight and yield per plant were studied. Analysis of variance revealed that there were significant differences among the genotypes studied for all the characters. In variability studies, among 25 genotypes AE 13 was identified as the best genotypes as it has recorded higher yield per plant followed by AE 7, AE 6 and AE21. Maximum phenotypic and genotypic co-efficient of variation (PCV and GCV) was found for yield per plant followed by plant height and number of fruits per plant. High heritability was recorded for all the characters except internodal length and fruit girth. Traits like plant height, number of branches per plant, node at first fruit, fruit length, number of fruits per plant, fruit weight and yield per plant had high heritability along with high genetic gain which reveals the predominance of additive gene action on these characters.

KEY WORDS : Variability, Heritability, Genetic advance, Okra

HOW TO CITE THIS ARTICLE : Kandasamy, R. (2015). Variability studies in okra (Abelmoschus esculentus L.). Asian J. Hort., 10(1) : 60-63. 